\title{
Stratigraphic correlation and provenance of the \\ Duitschland/Rooihoogte formation(s) and its implications for the interpretation of the Great Oxidation Event
}

\author{
JULIUS HAVSTEEN ${ }^{1}$, NICOLAS BEUKES ${ }^{2}$, LUCILE \\ ROUÉ $^{1}$, ILKA C. KLEINHANNS ${ }^{3}$ AND RONNY \\ SCHOENBERG $^{2,4}$
}

${ }^{1}$ Eberhard Karls University of Tuebingen

${ }^{2}$ University of Johannesburg

${ }^{3}$ University of Tuebingen, Geosciences

${ }^{4}$ University of Tuebingen

Presenting Author: julius.havsteen@uni-tuebingen.de

The correlation between the Duitschland formation and the Rooihoogte formation in the Transvaal Basin (South Africa) becomes critically important when viewed in the light of the Great Oxidation Event (GOE). That is because both formations record the transition from mass-independent to mass-dependent fractionation of sulfur isotopes. Some previous studies argue for a synchronous deposition of the Duitschland and Rooihoogte formations and thus regard them as the same sedimentary unit, but deposited at different water depths $[1,2,3]$. Other studies see them as two distinct entities, with the Duitschland formation predating the Rooihoogte formation [4, 5]. A time equivalent deposition of the formations points towards the GOE being an irreversible event. A decoupling of the two formations, on the other hand, would indicate an oscillating and dynamic atmospheric oxygen evolution across the GOE. Based on lithological, sequence stratigraphic and geochemical similarities, this work aims to correlate four drill cores from the CIMERAAgouron GOE Drilling project intersecting both the Duitschland and Rooihoogte formations. Our data indicate that the drill cores have the same provenance and thus might be viewed as one formation. In addition, geochemical discrimination diagrams coupled with zircon ages of the Duitschland formation by [6] suggest that the main source area must be a felsic igneous complex with an age of 2410-2575 Ma. To further test the complementary provenance of the Duitschland/Rooihoogte formation(s), we aim to utilize $\mathrm{Sr}-\mathrm{Nd}$ radiogenic isotope systematics as compositional tracers of the sediment source.

[1] Coetzee, L (2001) PhD thesis,University of Johannesburg; [2] Hoffman (2013) Chem. Geol. 362, 143-156; [3] Luo et al. (2016) Science Adv. 2.5; [4] Gumsley et al. (2017) PNAS 114, 1811-1816; [5] Moore et al. (2012) J. African Earth Sci. 64, 919; [6] Schröder et al. (2016) Precamb. Res. 278, 362-393. 